\title{
分光分析用鋳鉄試料の白銑化についで
}

\author{
鹿島 次 郎**. 一保田正明**
}

（昭和 44 年 1 月 13 日受理）

\section{White Solidification of Cast Iron Sample for Spectrographic Analysis}

\section{Jiro KASHIMA and Masaaki KUBOTA}

\author{
Casting Research Laboratory, Waseda University \\ (500, Tozuka 1-chome, Shinjuku-ku, Tokyo, Japan)
}

A study is made on the addition of elements to promote the white solidification of cast iron for the purpose of spectrographic analysis.

The results obtained are summarized as follows:

(1) Even if a thin plate sample is made by casting the melt in a copper mold, it is impossible to restrain the graphitization for samples having the saturation degree of carbon above 1.1.

(2) Little effect is observed when 1 to 5 per cent of tin is added to increase the chilling tendency and hence to improve the analytical precision.

(3) Addition of 1 per cent of chromium or tellurium ensures the white solidification of almost all samples whose saturation degrees are less than 1.3, and besides analytical precision and accuracy are improved for silicon and manganese by using these auxiliary elements.

\section{1. 緒言}

C, Si の高い鋳銑鉄で法黑鉛化しやすいために, 分光 分析の試料採取法の検討が必要となる. 通常, カントメ 一タやカントバックで処理される鉄鋼試料としては製鋼 用銑の占める割合が非常に多いため問題は少ないが，近 年, 鋳物用銑や鋳物工場での溶湯分析にカントバックが 使用されるようになつて，添加元素を用いた白銑化が試 みられるようになつた。比較的古い報告として， Bi と $\mathrm{Te}$ 定添加して水冷銅板上へ鋳込主方法 ${ }^{11}$ と, Te 它添加 乙て 銅鋳型へ鋳込む方法2 とがあり，その後になつて， $\mathrm{Te}$ または Ce 添加と各種鋳型の比較 ${ }^{3}$ 小よびダタタイ 儿鋳鉄に対する $\mathrm{Te}, \mathrm{Ce}, \mathrm{Bi}$ 添加と鋳鉄鋳型鋳込み初が 報告されている.

* 第 4 回応田スペクトロメトリ一東京討論会（1968年 11月）にて発表. 講演要旨集 p. 35.

** 早稲田大学鋳物研究所, 東京都新宿区戸塚 1 丁目 500 番地.

1) E.L. Both and G. Antonic: Foundry, 3, 149 (1961).

2）真鍋・金原：鉄と鋼，47, 1503 (1961).

3) 鹿島・久保田：分光研究，13,83 (1965).

4) 塚本 - 玉理 - 奥山：同上，16，7 (1967).
著者らは治金履歴の不明な鋳鉄試料の処理方法として 高周波再溶解法 ${ }^{5 \sim 7}$ を提案しているが，その際に添加元 素として使用できると思われるほとえどすべての元素を 検討し, $\mathrm{Sn}, \mathrm{Cr}, \mathrm{Te}$ を好ましい元素に挙げている. 今

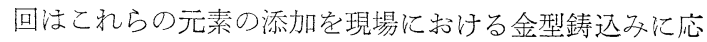
用し，従来の報告に欠けていると思われる点に主眼を沶 いて実験を行なつた。すなわち, 添加元素を用いること により, 定量可能となる試料の組成範囲を炭素飽和度の 值で明らかにしたのでその結果を報告する.

なお，黑鉛化しやすい鋳物用銑鉄としては

JIS 1 種 1 号 D (普通用)

C $>3.30$, Si $2.61 \sim 3.50$, Mn 0.30 0.90, $\mathrm{P}<0.450, \mathrm{~S}<0.050 \%$

2 種丙 2 号 (可鍛鋳鉄用) $\mathrm{C}<3.50, \mathrm{Si}>4.51, \mathrm{Mn}<1.10, \mathrm{P}<0.200$, $\mathrm{S}<0.045, \mathrm{Cr}<0.035 \%$

3 種 2 号 (球状黒鉛鋳鉄用) $\mathrm{C}>3.40, \mathrm{Si}<3.50, \mathrm{Mn}<0.50, \mathrm{P}<0.150$, $\mathrm{S}<0.045, \mathrm{Cr}<0.035 \%$

5）鹿島・久保田：分光研究. 16, 119 (1967).

6) 同上：同上，16,207 (1968).

7）鹿島・久保田・川崎：同上， 17, 215 (1969). 
などが挙げら机る。

\section{2. 装置と分析条件}

$\mathrm{Si}, \mathrm{Mn}$ の定量に使用した装置と分析条件を Table 1 行示す.

Table 1. Apparatus and analytical conditions

Excitation: Castings Research Laboratory type Universal Source Unit

$L=50 \mu \mathrm{H}, C=10 \mu \mathrm{F}, R=5 \Omega, V=800$ volt

Analytical gap $=2 \mathrm{~mm}$, Auxiliary gap $=10 \mathrm{~mm}$ Upper electrode $=$ Hitachi spectroscopic graphite $6 \phi 120^{\circ}$ cone

Spectrograph: Shimadzu grating spectrograph, GE-340

Pre-spark time $=30 \mathrm{sec}$, Exposure time $=40 \mathrm{sec}$ Slit width $=20 \mu$, Slit height $=2 \mathrm{~mm}$

Photographing: Spectroscopic Fuji plate Process type $10.1 \times 25.2 \mathrm{~cm}$

Development $=5 \mathrm{~min} .20^{\circ} \pm 0.5^{\circ} \mathrm{C}$, Fixing $=15 \mathrm{~min}$.

Wash $=15$ min.

Photometry: Shimadu microphotometer PD-20

\section{3. 実験方法と実験結果}

\section{1 添加元素と顕微鏡組織}

キュポラ溶解をた泣高周波溶解した溶晹を1 00 ２00 : gr. とり, 鋳込温度 $1200 \sim 1350^{\circ} \mathrm{C}$ の範囲で常温に保持 した金型に鋳込む. 添加元素としては $\mathrm{Sn}, \mathrm{Cr}, \mathrm{Te}$ 它使 用し, 添加量法前報 ${ }^{5} 7$ の結果に基づいて $\mathrm{Sn} 5 \%, \mathrm{Cr}$ $1 \%$ としたが，このような空気中での添加では多量の Sn がドロスとなるため, Sn 1\% 添加もあわ斿て試み, $\mathrm{Sn}, \mathrm{Cr}$ と比較する目的で $\mathrm{Te}$ も同量とした. 添加元素

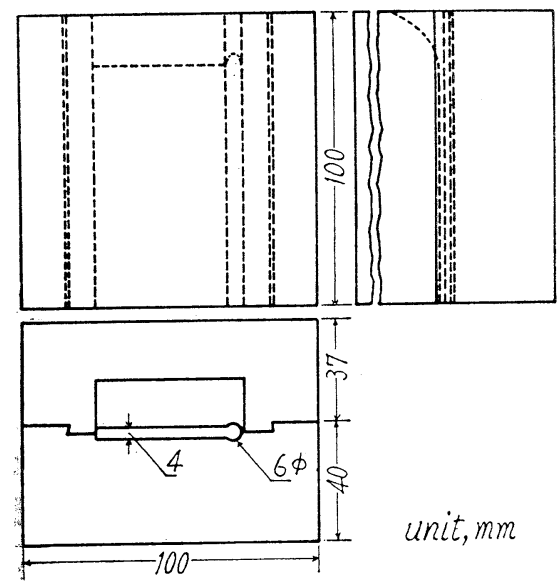

Fig. 1. Copper mold for sampling.
の歩留まりは平均して Sn $71.4 \%, \operatorname{Cr} 89.0 \%, \mathrm{Te} 41.3 \%$ であつた。金型としては，Fig. 1 に示すような銅鋳型 用い, 厚さ $4 \mathrm{~mm}$ の板状試料之直径 $6 \mathrm{~mm}$ の棒状試 料を採取して断面の顕微鏡組織を確認した。

成分組成が C 3.04, Si 4.31, Mn 0.42, P 0.010, S $0.008 \%$ の試料の顕微鏡組織 $(\times 150)$ を Photo. 1 亿 示す. この試料の炭素飽和度は $S_{c}=\frac{T . C .}{4.23-\mathrm{Si} / 3.2}=1.06$ に相当する. 同様にして $S_{c}=1.2$ (C 3.92, Si 3.01, Mn 0.04, P 0.009, S 0.008\%) の試料の組織定 Photo. 2 飞, $S_{c}=1.3$ (C 4.68, Si 2.05, Mn 0.60, P 0.011, S 0.009\%) の試料の組織を Photo. 3 に示す. Fig. 2 はこれらの試料すべてに関して光電測光法により FeII 2926 スペクトル線の強度一時間曲線を求めた結果であ る. 図中の記号で $W$ は白銑， $M$ は斑銑，G はネズミ 銑組織であること定している. $W$ と $M$ の試料で は光電子増倍管への印加電圧 750 volt で測定してい るが， $G$ の試料では $W$ や $M$ より高い強度が出ること 劣考虑して印加電圧を 650 volt に下げている。したが つて相対強度の比較注写真測光法で求めて図中に数字で 示してある.この数字は露光時間 40 秒間の FeII 2926 スペクトル線の強度であり, $\mathrm{S}_{c}=1.06$ 添加元素なしの 試料定 1 とした時の值俗算されている. 一般に $S_{0}$ が 大きくなるほど強度も上昇する傾向が認められる。

$S_{c}=1.06$ の試料では添加元素の有無に関係なく白銑 化乙, $\mathrm{Fe}$ スペクトル線強度は放電時間の経過と共に次 第に上昇する傾向を持つている. $S_{c}=1.2$ の試料になる と, 添加元素のない試料と $\mathrm{Cr}$ または $\mathrm{Te}$ を添加した試 料は白銑化しているが, Sn 添加試料ではいずれも微細 な片状黑鉛と塊状のキッシュ黑鉛が認められ素地にはレ デブライトとパーライトが混在している。このような試 料では放電開始後 30 秒前後で最大強度に到達し, 相対 的な強度としても白銑試料よりはるかに高值を示してい る. 今回の結果は, 再溶解した試料に関して写真測光法 で強度-時間曲線を求めた結果6) と非常によく一致して いる.

$\mathrm{S}_{c}=1.3$ になると, $\mathrm{Cr}$ や $\mathrm{Te}$ 壱添加しても完全な白 銑化注困難である绍，強度一時間曲線の形の上からは白 銑とみなしうる。添加しない試料や Sn 添加試料はネズ ミ鉡鉄であり，レデブライト素地に特に大きなキッシュ 黑鉛の存在する試料では, 強度-時間曲線も中間的な傾 向を持つているのがわかる。

以上のことから次のようなととがいえる。すなるち $S_{c}$ の高い試料で黒鉛が晶出したとしても，その大きさ 另微細でありマトリックスがレデブライトと初晶セメン タイトより成る試料では白銑として分析試料に加えても 
Addition element

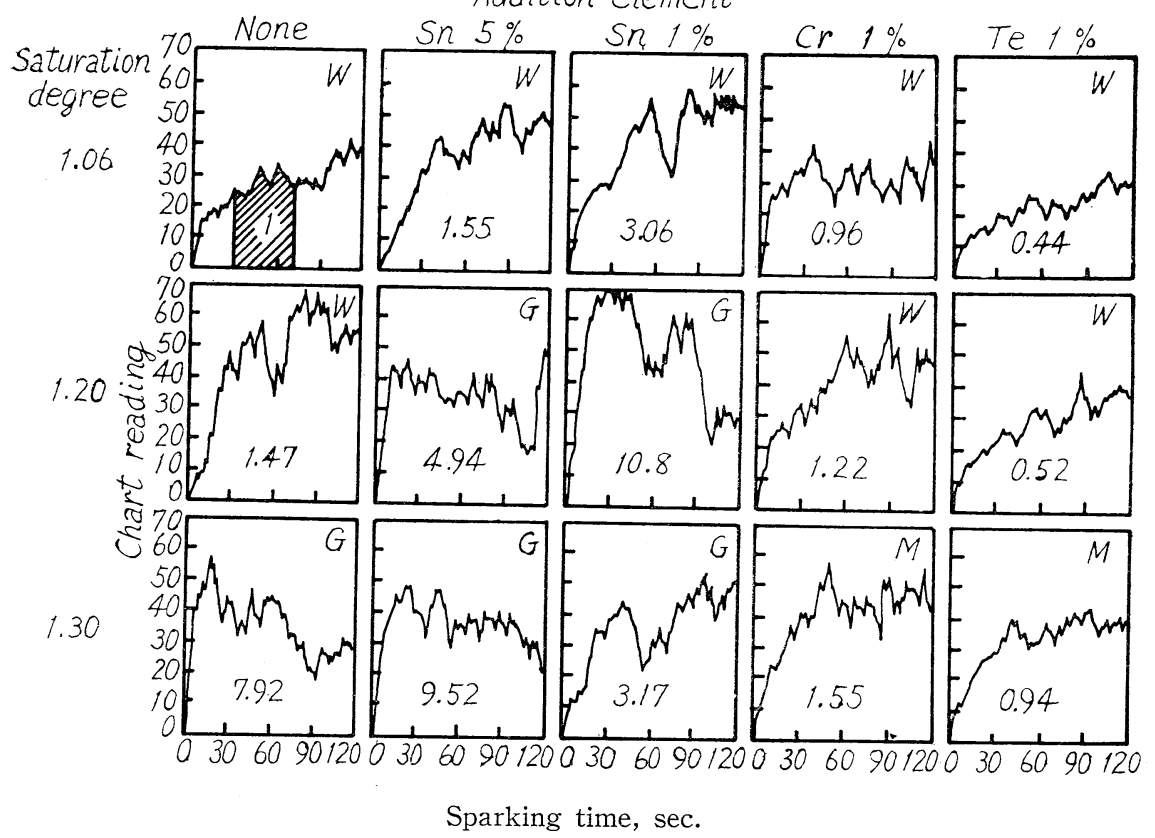

Fig. 2. Fe II 2926 spectral line intensity-time curves for various samples W: White cast iron. M: Mottled iron. G: Grey cast iron.

よいものと思わ秃る。

なおネズミ鋳鉄試料のスペクトル線強度に見られる 放電開始直後の立ち上がり現象の原因定調べるため，ク レータの生成過程を撮つた写真が Photo. 4 に示されて いる。こ秃は，放電休止期間を長くとつた間けつ放電に より，スパーク回数 1〜30 の間で白銑とネズミ銑のク レータを比較した結果である。これによると片状黒鉛の 存在が, スパークによる試料面の破壊とクレータの拡大 を促進しているように思われる。

\section{2 白銑化の範囲}

縦軸に C\%, 横軸に $\mathrm{Si} \%$ をとつて組織図を描き, 白 銑化する範囲を示すことにする。図中の記号としては，

\section{$\square \triangle \bigcirc$ 白銑組織 \\ $\square \triangle($ 斑銑組織}

A ネズミ銑組織

它使用した．Fig. 3 は添加元素を用いない場合の金型 鋳込タ試料の組織である。

図中の下の実線は Maurer の鋳鉄組織図における白 銑領域と斑銑との境界線, 上の実線は同じく普通鋳鉄と フェライト鋳鉄との境界線である。したがつて標準的な 冷却速度の場合に比らべてはるかに白銑領域は広がつて いることがわかり， $S_{c}>1.1$ が黒鉛を生ずる範囲になつ ている.ただし，一般には Fig. 1 に示した金型でえら
れる試料より厚さあるいは直径の大きな試料を採取して いる場合も多いので，そのような場合には $S_{c}=1.1$ の 試料ですでに添加元素を用いるべき範囲に入つているも のと考えるべきであるう。

Fig. 4 は Sn 5\% 定添加して 金型へ鋳込えだ試料の 組織図であり, Fig. 5 は Sn 1\%,Fig. 6 は Cr 1\%,

Fig. 7 は Te 1\% の場合の組織図军示している.

$\mathrm{Sn}$ は溶鉄へのC の溶解度を減少させる元素であるか らキッシュ黑鉛はむしろ出やすくするわけであるが， 凝固後のセメンタイトの分解孛妨げて黑鉛の粗大化を防 ぐ効果はある.ただし $S_{c}=1.2$ で完全に黒鉛化する. Cr は C の溶解度を増すばかりでなく，いわゆるレデブ ライト凝固学助長する元素であるために, $S_{c}=1.3$ に近 い範团まで白銑化が可能であり，このことはほとえどす ベての鋳物用銑および鋳鉄を白銑化しうることを意味し ている. Te の添加は $\mathrm{Cr}$ と同程度の効果が期待できる. すでに指摘したように，レデブライト素地であるなら ぼ微細な黒鉛が多少晶出しても Si や Mn の分析は可能 と思われるが，C 分析に対してはやはり問題になると考 え㪍ばならない。キッシュ黒鉛の晶出は高温溶解により 防ぎうるが，分析試料採取の際にはその量は少量であ り，乙かも添加元素を加えてかくはえするなどの操作を 行なえば，鋳込温度は液相線すれすれになる場合が多 


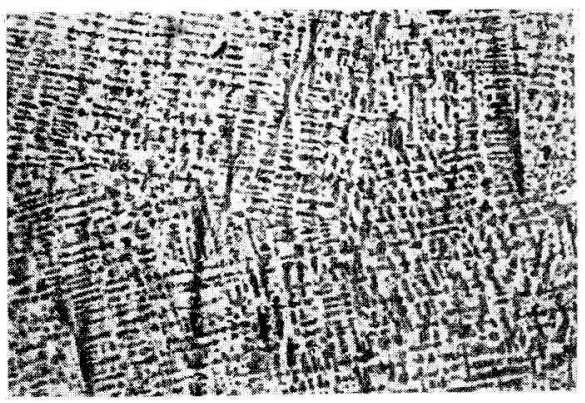

Chemical composition C 3.04 Si 4.31 Mn 0.42 P $0.010 \quad 5.0008 \%$
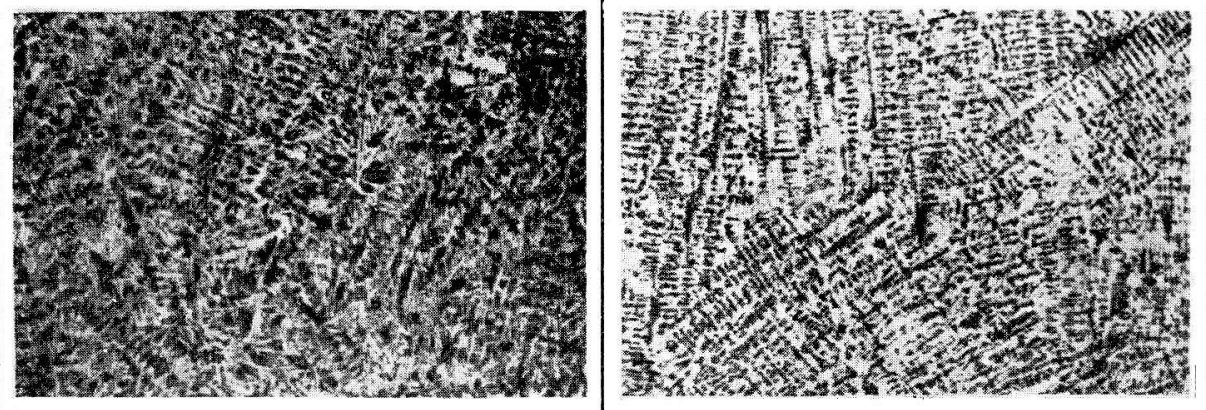

Sn $5 \%$ addition

sn $1 \%$ addition

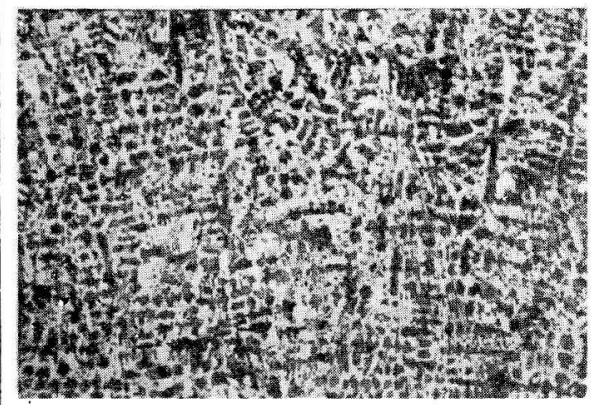

Cr $1 \%$ addition

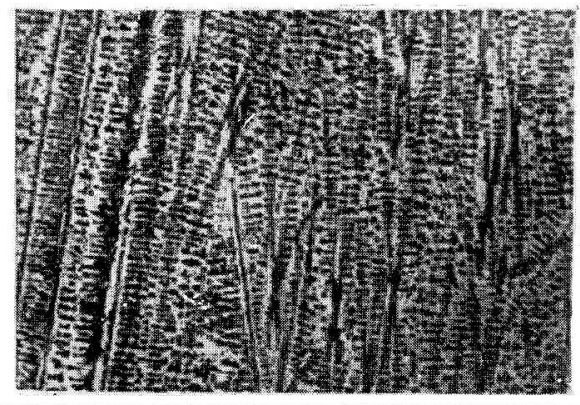

Te $1 \%$ addition

Photo. 1. Microstructure of samples whose saturation degree corresponds to 1.06 . 


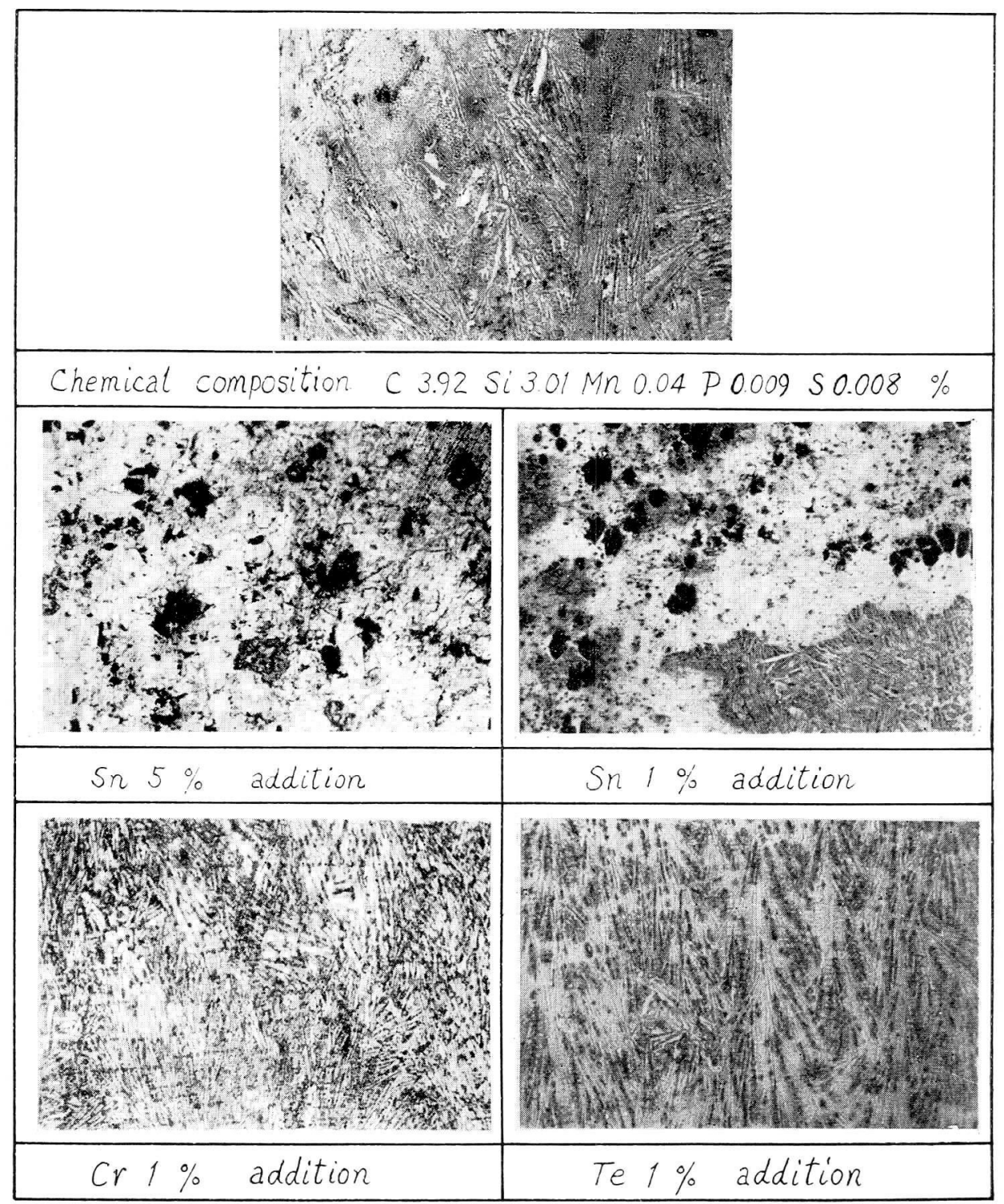

Photo. 2. Microstructure of samples whose saturation degree corresponds to 1.20. 


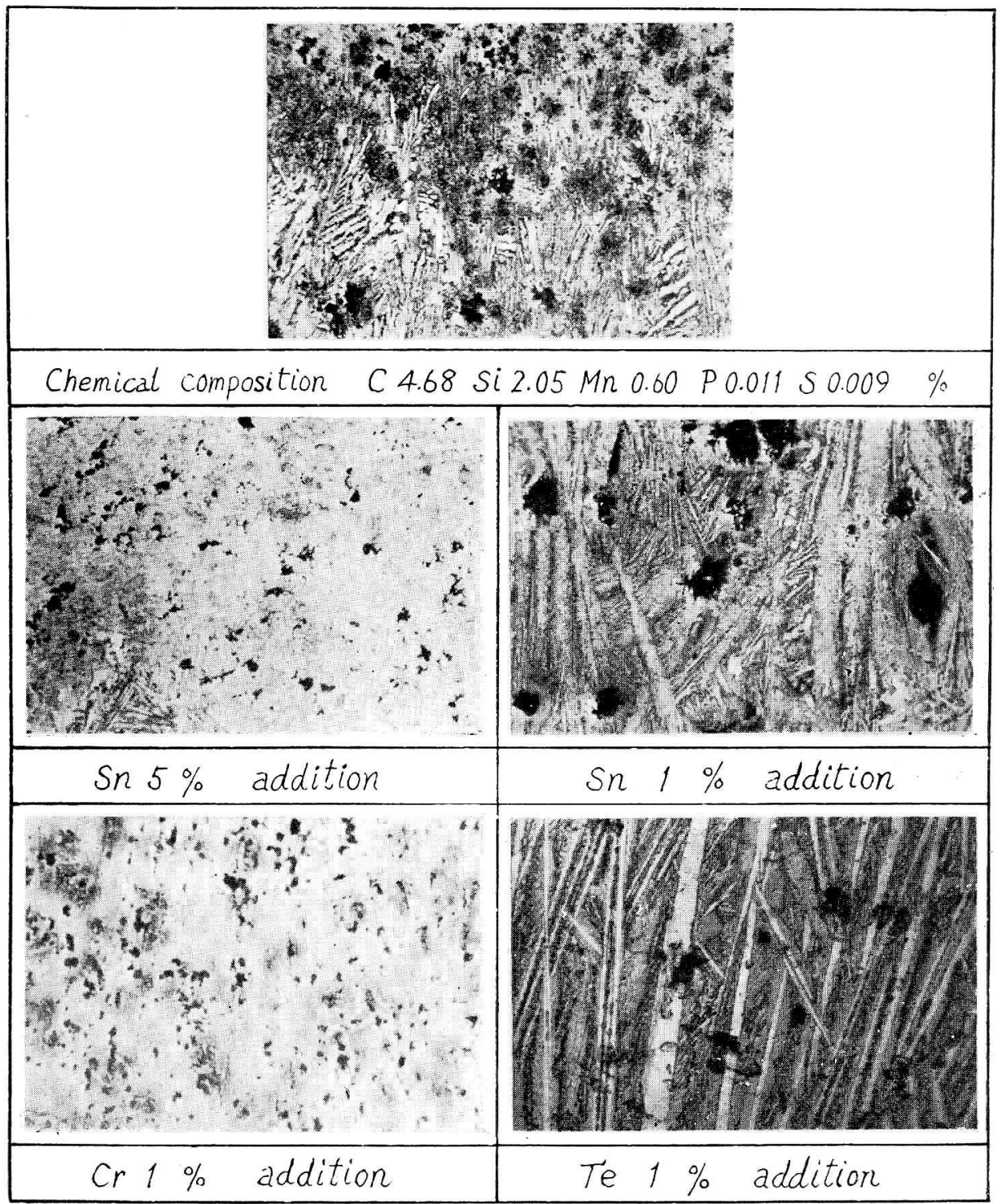

Photo. 3. Microstructure of samples whose saturation degree corresponds to 1.30. 
White cast iron
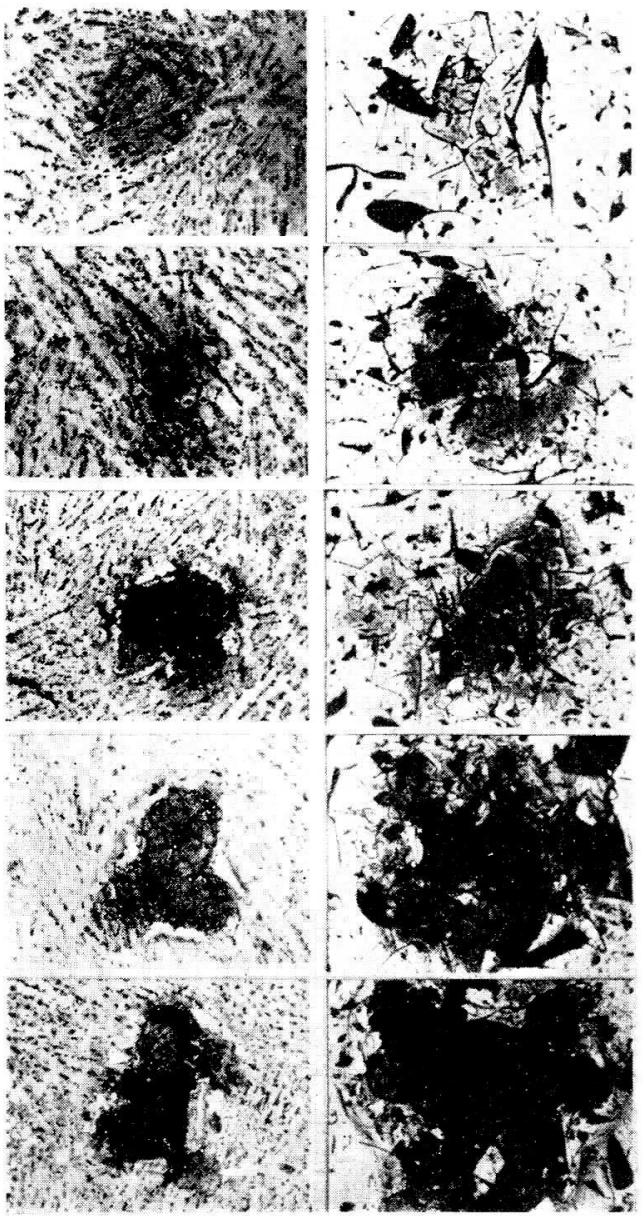

Photo. 4. Appearance of crater at beginning of spark discharge.

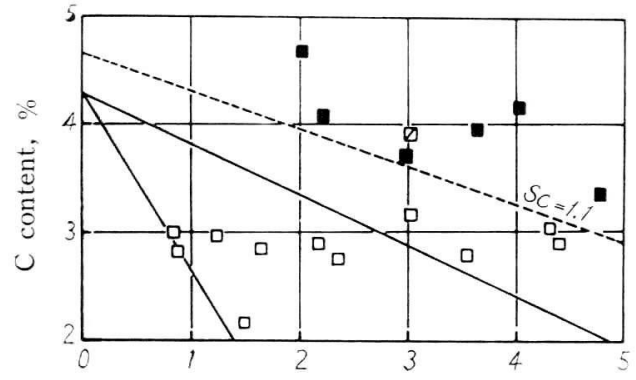

Si content, \%

Fig. 3. Structure diagram of cast iron samples.
Spark (number of times)

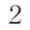

Fig. 4. Structure diagram of cast irons sampled with additions of $5 \%$ tin.

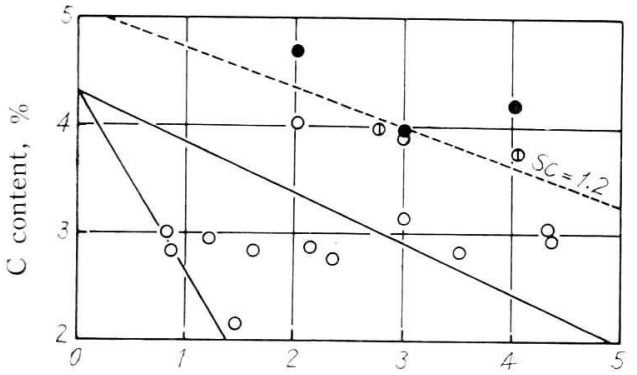

Si content, \%

Fig. 5. Structure diagram of cast irons sampled with additions of $1 \%$ tin.

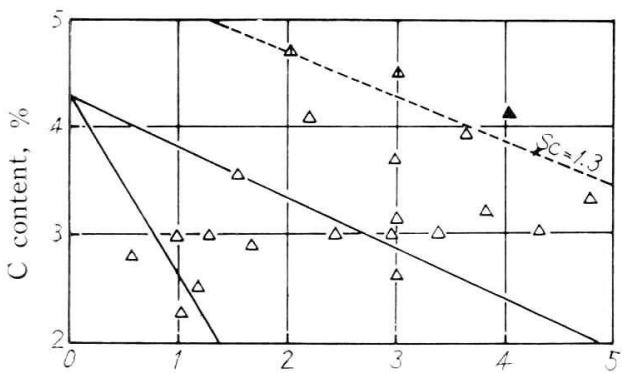

Si content, \%

Fig. 6. Structure diagram of cast irons sampled with additions of $1 \%$ chromium.

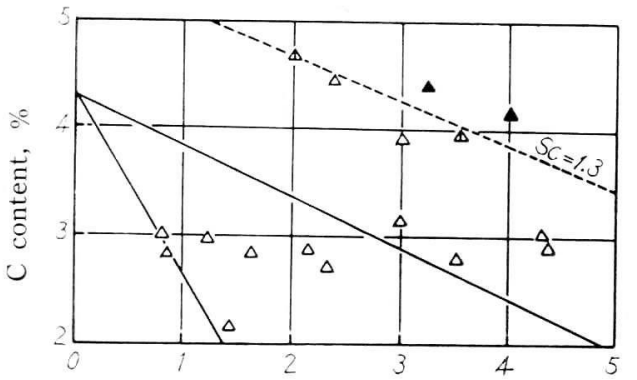

Si content, \%

Fig. 7. Structure diagram of cast irons sampled with additions of $1 \%$ tellurium. 
多い. 塚本ら ${ }^{4}$ 注，鋳込温度が $1250 \sim 1170^{\circ} \mathrm{C}$ の間では 分析結果に対して有意差のないことを報告しているが， やはりキッシュ黑鉛晶出を防ぐ意味より高温鋳込みをす すかている。

F. Neumann $5^{8)}$ によと溶鉄への C の溶解度は次 式で与えられる。

$$
\begin{aligned}
\% \mathrm{C}= & 1.30+2.57 \times 10^{-3} t\left({ }^{\circ} \mathrm{C}\right)+\triangle \% \mathrm{C}(\mathrm{Si}) \\
& +\triangle \% \mathrm{C}(\mathrm{Mn})+\triangle \% \mathrm{C}(\mathrm{S})+\triangle \% \mathrm{C}(\mathrm{P})+\cdots
\end{aligned}
$$

ここで $\triangle \% \mathrm{C}(\mathrm{X})$ 性， $\mathrm{Fe}-\mathrm{C}-\mathrm{X}$ 系合金の炭素溶解度と $\mathrm{Fe}-\mathrm{C}$ 系合金の炭素溶解との差を意味しており，各 $\triangle$ 函 数は

$\triangle \% \mathrm{C}(\mathrm{Si})=-0.31 \times \% \mathrm{Si}, \triangle \% \mathrm{C}(\mathrm{Mn})=0.027 \times \% \mathrm{Mn}$, $\triangle \% \mathrm{C}(\mathrm{S})=-0.40 \times \% \mathrm{~S}, \triangle \% \mathrm{C}(\mathrm{P})=-0.33 \times \% \mathrm{P}$

である.これらの式を用いてたとえば Photo. 3 の試料 の成分 \%より温度を求めると $t=1556^{\circ} \mathrm{C}$ となる。すな わち, 溶湯の温度が $1556^{\circ} \mathrm{C}$ 以下になれば， $4.68 \%$ 含 まれているCの一部が黒鉛として液相中に晶出してくる ことになる. $\mathrm{Cr} の \triangle$ 函数は $\triangle \% \mathrm{C}(\mathrm{Cr})=0.063 \times \% \mathrm{Cr}$ であるから，1\%の Cr を添加しても晶出温度が $24^{\circ} \mathrm{C}$ 下がつて $1532^{\circ} \mathrm{C}$ になるたすきない。

ところで $100 \mathrm{gr}$ あるいは $200 \mathrm{gr}$ という少量の溶湯 の取鍋中での冷却曲線を調べてみると Fig. 8 のごとく である。過共晶鋳鉄の溶湯では，液相線温度が不明睹で あるが，冷却速度は組成によらずほぼ同一であるから， この図から, 初晶晶出までの閒の泠却速度を求めると, $100 \mathrm{gr}$ では約 $180^{\circ} \mathrm{C} / \mathrm{min}, 200 \mathrm{gr}$ では約 $120^{\circ} \mathrm{C} / \mathrm{min}$ であることがわかる。したがりて仮に $200 \mathrm{gr}$ の溶湯を $1500^{\circ} \mathrm{C}$ で取鍋にとつたとしても 1 分後には $1380^{\circ} \mathrm{C}$ ま で下がることになる。この温度はちょうど Photo. 2 の

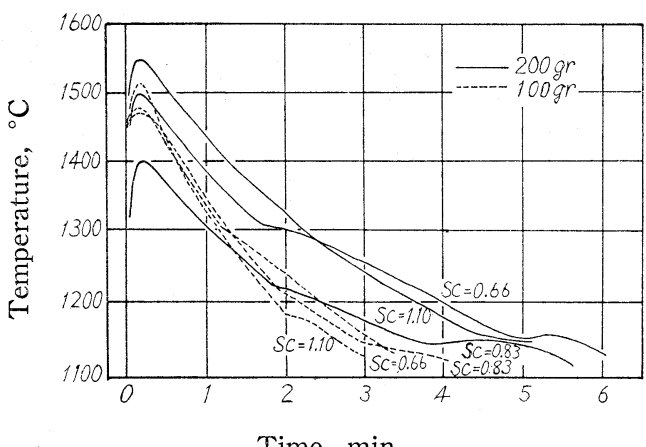

Fig. 8. Cooling curves of melts for analytical samples.

8) F. Neumann, H. Schenck und W. Patterson: Giesserei, 47, 25 (1960).
試料の黑鉛晶出温度に相当するので, $S_{c}=1.2$ 要の溶湯で は1分以内に金型へ鋳达まなければ，キッシュ黑鉛が必 ず晶出することになる。黑鉛晶出温度が $1500^{\circ} \mathrm{C}$ を越え る $S_{c}=1.3$ の試料では完全な白銑化は不可能と考えら れる。

\section{3 分析值の精度と正確度}

分析值の精度および正確度に与える添加元素の効果を 調べるため, $\mathrm{Si}, \mathrm{Mn}$ の定量を行なつた。検量線を作 るために使用した標準試料の治金履歴と化学分析值を Table 2 に示す.

Table 2. Standard samples for analysis of

\begin{tabular}{|c|c|c|c|c|c|}
\hline \multirow{2}{*}{$\begin{array}{l}\text { Sample } \\
\text { number }\end{array}$} & \multirow{2}{*}{$\begin{array}{l}\text { Melting } \\
\text { furnace }\end{array}$} & \multirow{2}{*}{$\begin{array}{c}\text { Addi- } \\
\text { tion } \\
\text { element, } \\
\%\end{array}$} & \multicolumn{3}{|c|}{$\begin{array}{l}\text { Value of chemical } \\
\text { analysis, } \%\end{array}$} \\
\hline & & & $\mathrm{Si}$ & $\mathrm{Mn}$ & C \\
\hline $\begin{array}{l}1 \\
2 \\
3 \\
4 \\
5 \\
6 \\
7\end{array}$ & $\begin{array}{c}\text { Kryptol } \\
\text { "I } \\
\text { "I } \\
\text { "I } \\
\text { "I } \\
\text { "I } \\
\text { " }\end{array}$ & $\begin{array}{c}\text { None } \\
\text { "1 } \\
\prime \prime \\
\prime \prime \\
\prime \prime \\
\prime \prime \\
\prime \prime\end{array}$ & $\begin{array}{l}0.62 \\
0.65 \\
1.27 \\
1.44 \\
1.85 \\
3.29 \\
3.81\end{array}$ & $\begin{array}{l}0.36 \\
0.20 \\
0.50 \\
0.63 \\
0.71 \\
1.42 \\
1.02\end{array}$ & \\
\hline $\begin{array}{r}8 \\
9 \\
10 \\
11 \\
12 \\
13 \\
14 \\
15\end{array}$ & $\begin{array}{c}\text { HFI } \\
\prime \prime \\
\prime \prime \\
\prime \prime \\
\text { Cupola } \\
\text { HFI } \\
\prime \prime \\
\prime \prime\end{array}$ & $\begin{array}{c}\mathrm{Sn} \\
\prime \prime \\
\prime \prime \\
\prime \prime \\
\prime \prime \\
\prime \prime \\
\prime \prime \\
\prime \prime\end{array}$ & $\begin{array}{l}0.60 \\
1.00 \\
1.04 \\
1.68 \\
2.00 \\
2.02 \\
3.01 \\
4.31\end{array}$ & $\begin{array}{l}0.20 \\
0.25 \\
0.38 \\
0.60 \\
0.64 \\
0.91 \\
0.40 \\
0.42\end{array}$ & $\begin{array}{l}2.80 \\
3.00 \\
2.24 \\
3.94 \\
\\
3.16 \\
3.13 \\
3.04\end{array}$ \\
\hline $\begin{array}{l}16 \\
17 \\
18 \\
19 \\
20\end{array}$ & $\begin{array}{c}\text { HFI } \\
\prime \prime \\
\prime \prime \\
\prime \prime \\
\prime \prime\end{array}$ & $\begin{array}{cc}\mathrm{Sn} & 1 \\
\prime \prime & \\
\prime \prime & \\
\prime \prime & \\
\prime \prime & \end{array}$ & $\begin{array}{l}0.39 \\
0.87 \\
1.62 \\
2.35 \\
4.38\end{array}$ & $\begin{array}{l}0.15 \\
0.31 \\
0.49 \\
0.72 \\
1.10\end{array}$ & $\begin{array}{l}2.16 \\
2.82 \\
2.84 \\
2.35 \\
2.88\end{array}$ \\
\hline $\begin{array}{l}21 \\
22 \\
23 \\
24 \\
25 \\
26 \\
27 \\
28 \\
29\end{array}$ & $\begin{array}{c}\text { HFI } \\
\prime \prime \\
\prime \prime \\
\prime \prime \\
\prime \prime \\
\text { "' } \\
\text { Cupola } \\
\text { HFI } \\
\prime \prime\end{array}$ & $\begin{array}{l}\mathrm{Cr} \\
\text { " } 1 \\
\prime \prime \\
\prime \prime \\
\prime \prime \\
\prime \prime \\
\prime \prime \\
\prime \prime \\
\prime \prime\end{array}$ & $\begin{array}{l}0.60 \\
1.00 \\
1.20 \\
1.30 \\
1.68 \\
2.02 \\
2.06 \\
2.95 \\
4.08\end{array}$ & $\begin{array}{l}0.20 \\
0.03 \\
0.95 \\
0.37 \\
0.50 \\
0.91 \\
0.65 \\
0.80 \\
0.55\end{array}$ & $\begin{array}{l}2.80 \\
3.00 \\
2.50 \\
2.29 \\
2.88 \\
3.16\end{array}$ \\
\hline $\begin{array}{l}30 \\
31 \\
32 \\
33 \\
34\end{array}$ & $\begin{array}{c}\text { HFI } \\
\text { "/ } \\
\prime \prime \\
\prime \prime \\
\prime \prime\end{array}$ & $\begin{array}{cc}\mathrm{Te} & 1 \\
\prime \prime & \\
\prime \prime & \\
\prime \prime & \\
\prime \prime & \end{array}$ & $\begin{array}{l}0.39 \\
0.87 \\
1.62 \\
2.35 \\
4.38\end{array}$ & $\begin{array}{l}0.15 \\
0.31 \\
0.49 \\
0.72 \\
1.10\end{array}$ & $\begin{array}{l}2.16 \\
2.82 \\
2.84 \\
2.35 \\
2.88\end{array}$ \\
\hline
\end{tabular}
silicon and manganese

HFI: High Frequency Induction Furnace.

Table 1 の定量条件を用いて作成した Si の検量線を Fig. 9 に, Mnの検量線を Fig. 10 に示す. Si や Mn の含有量は，添加元素安加える前の溶湯の化学分析值で 


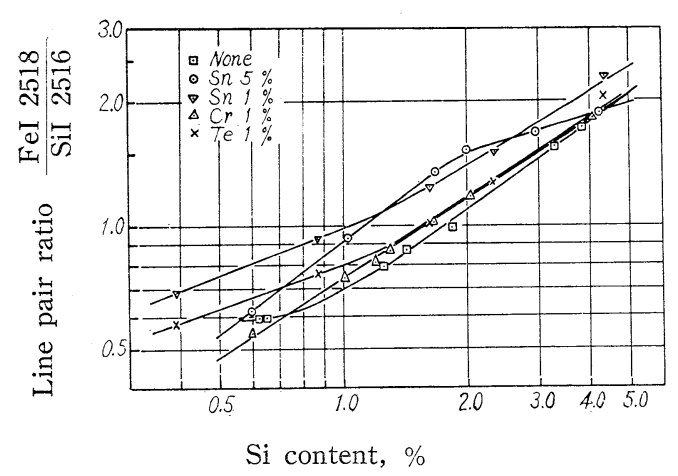

Fig. 9. Working curves for silicon.

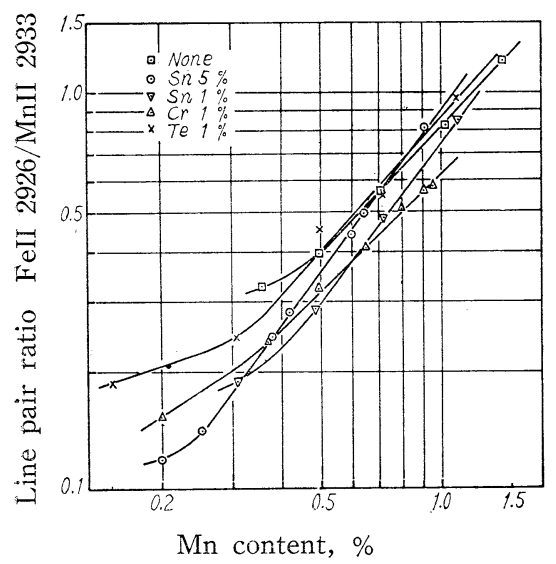

Fig. 10. Working curves for manganese.

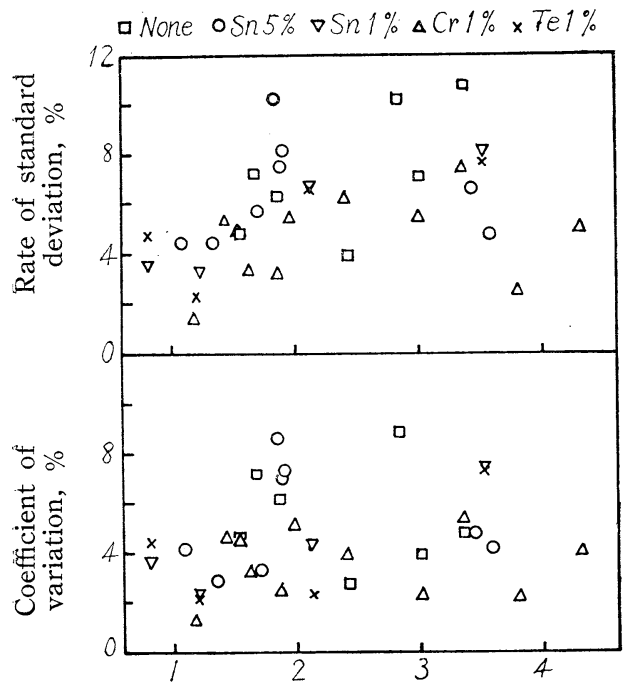

Si content, \%

Fig. 11. Precision and accuracy of silicon analysis.

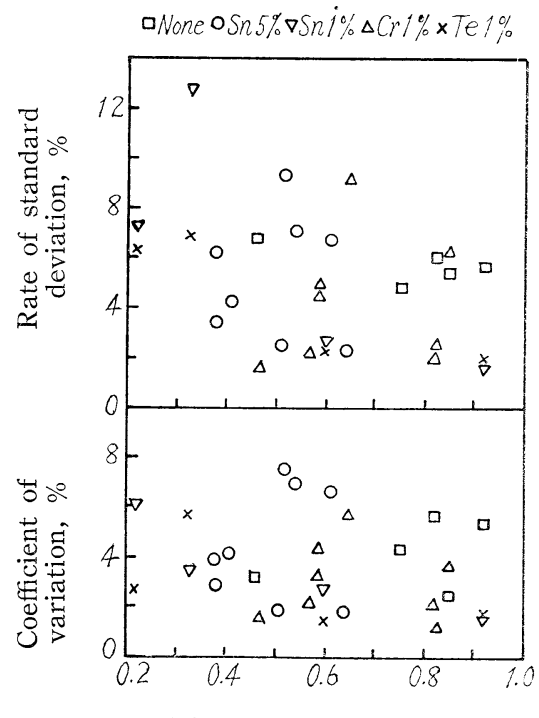

Mn content, \%

Fig. 12. Precision and accuracy of manganese analysis.

あるから添加量の差による影響があり，また，Sn 品 $\mathrm{Si}$ スペクトル線の強度を高める等の索果が現われて，各検 量線にはかなりのずれが認められる。

標準試料と同様の治金履歴をもつ未知試料をこれらの 検量線で各試料 10 回ずつ定量して, 変動係数之標準偏 差率を算出した。その結果を Fig. 11 および Fig. 12 に図示する。

精度, 正確度共に試料によりかなり值が汸らつくが， これは C 含有量の差によるところがあるものと思和れ る. 特にその傾向は, Sn 添加試料や添加元素なしの試 料に打いて著しい. $\mathrm{Cr}$ 添加試料や $\mathrm{Te}$ 添加試料で法此 較的安定しており，その值も低くなつている。たと先济 $\mathrm{Si}$ の平均の変動係数は添加元素なしの場合 $5.42 \%$ 之最 も大きく, Cr 添加の場合 $3.53 \%$ と最も小さい. Mn で 注 Sn $5 \%$ 添加試料の变動俰数が最も大きく平均 $4.47 \%$ であるのに対し， $\mathrm{Te}$ 添加試料のそれは $2.88 \%$ と最小 の值を示している。標準偏差率注, $\mathrm{Si}, \mathrm{Mn}$ 共沉 Cr を 添加した場合に平均して最も小さな值が得られている.

一般に Si の含有量が多くなるほど正確度は低くなり， 逆に Mnではその含有量が增加するほぞ正確度が向上す る傾向が認められるが，これは前者が黑鉛化促進元素で あり，後者が白銑化促進元素であることに関倸するもの と思われる. Si や Mn そ秃自体の含有量に上るこのよ うな影響を少なくするために，常に $\mathrm{Cr}$ あるい法 $\mathrm{Te}$ 在 添加することが望ましい， Cr と Te とではその効果に 大差はないといえるが，高温にお㤝る Te の高い蒸気圧 
とその毒性を考慮すると， Cr 它含告低合金鋳鉄以外の 鋳鉄あるいは銑鉄に対して Cr の添加が最良と考えられ る. Sn 添加の効果が期待できなかつた理由は, Snが キッシニ黑鉛の晶出を助長するととと酸化してドロスを 生ずることによるるのであるう。

\section{4. 結訔}

崖素飧和度の高い鋳銑鉄を分光分析用試料として金型 採取する際に，添加元素として有効な元素について検討 し，次のような結果を得た。

1) 泠却速度の大きい銅鋳型で厚さ $4 \mathrm{~mm}$ の板状試 料岂得る場合でも, 添加元素がなければ $S_{c}>1.1$ で 黒鉛化する。
2) Sn の添加はキッシニ黑鉛を出やすくするが， Cr あるいは Te の添加は白銑化を著しく促進し， $S_{c}=$ 1.3 亿近い範囲の溶湯にまで適用できる.

3）分析試料用の少量の溶湯では高温鋳込みが不可能 なため， $S_{c}=1.3$ では添加元素を用いても必ず黒鉛 方晶出する。

4） Cr あるいは Te の添加により, Si p Mn の分 析精度および正確度は向上する. Sn 添加の效果は あまり認められない。

ところで, 実際の現場分析試料の内で $S_{c}$ が 1.3 を越: える試料はほとえどないといえるので，1％のCr を添 加して銅鋳型に鋳込さことにより常に精度の安定した分 析結果が得られるものと思われる。

Chemical Abstract に採録：分光研究に発表された化学系統の論文はすべて Chemical Abstract に採録されておりますから奮って御投稿下さい. 